\title{
Managerial Ability in Measuring Financial Performance
}

\author{
$1^{\text {st }}$ Ade Sri Ulita* \\ Department of Accounting, Faculty of \\ Business and Economic \\ Universitas Musamus \\ Merauke, Indonesia \\ ulita_akuntansi@unmus.ac.id
}

\author{
$2^{\text {st }}$ Kristianus Hiktaop \\ Department of Accounting, Faculty of \\ Business and Economic \\ Universitas Musamus \\ Merauke, Indonesia \\ hiktaop_akuntansi@unmus.ac.id
}

\author{
$3^{\text {st }}$ Paulus Peka Hayon \\ Department of Accounting, Faculty of \\ Business and Economic \\ Universitas Musamus \\ Merauke, Indonesia \\ pauluspeka@unmus.ac.id
}

\begin{abstract}
For a company, the provisions and decisions by the company's leaders can determine the level of managerial ability in managing a company that means managerial ability is needed to achieve the target. Managerial ability in managing this company can be seen from the results of the company's performance within a certain period. The measurement of managerial ability is done using DEA while financial performance assessments are measured used ratios. The companies in this research as sample research are emiten subsector toll road, port, airport and transportation listed IDX 2015-2018. The results used multiple linear regression analysis showed that emiten who have a good managerial ability will significantly impact to financial performance. This suggests, financial performance is influenced by management decisions and decrees set by management.
\end{abstract}

\section{Keywords: DEA, financial performance}

\section{INTRODUCTION}

For an entity, management is a stakeholder that is expected to create a conducive working atmosphere through the attitude of controlling. In addition to being a companies that has an influence in controlling, management has a power to make the decision expected to take and make a strategic plan to achieve the high efficient levels. In this study, we focused the attention on the style of managerial ability as well as managerial knowledge in understanding the business carried out so as to be able to change the resources owned, valuation and bussiness forecasts in the future ahead to achieve better performance which provides a small impact of the occurrence of risk of business failure and audit risk [1].

This high level of efficiency influenced of the management's ability to capitalize the resources owned that will impact the entity's financial performance, including through the stock price measured by the financial ratios to assess the performance of management, the value of the company and the amount of compensation received while the management capability is measured using data. Data envelopment Analysis (DEA) according to is a statistical procedure that can be used to assess and evaluate the efficiency levels of the relativity of separate entities decision making units (DMU) which each DMU can convert inputs into outputs [2]

For investors, to measure a company whether looks good in running its business, investors need a tool that can improve their confidence. One of them is to see the managerial abilitys in managing the company to reduce the high level of risk. Managerial abilitys in managing business for investors can be seen from the company's performance results that are

reflected in the EPS and ROI. Whether, managerial abilitys in managing the business are able to influence the level of EPS and ROI values or not. Therefore, this research uses managerial abilitys as an independent variable to test its impact on the company's performance. Research shows that managerial abilitys have a positive effect on profit management, quality gains and company performance [3] while providing empirical evidence of DEA's ability to measure managerial prowess in superior comparisons with other measuring instruments. Another opinion said that the management with a special and responsible ability in the field are those who have [4] skills from experience, education and intelligence levels.

The benefits of DEA in measuring managerial abilities are the author's reason for using DEA as a measuring instrument to assess managerial stability in managing, controlling and making decisions, while measuring financial performance with the analysis of financial statements in the form of ratios as a result of management skills in managing, controlling and making decisions at the expense of resources owned is one way of measuring the performance of entities that can be seen from Financial statements that have been compiled. This is done in order to avoid the misinterpretation of financial statements that are beneficial for decision making [5] which is the result of an accounting process that can be used as a communication tool between users As well as the company's financial performance gauge [6]. Using the analysis of financial statements entities can analyse the strengths, weaknesses, opportunities and challenges to organize and plan needs by utilizing the advantages and weaknesses they have with how to compare the values of each specific account researched.

Financial performance can be measured using a financial ratio for the purpose of facilitating management to analys the symptoms of financial statements and how to anticipate them. The use of this financial ratio is also carried out as a standard comparative assessment whether company values are considered good or bad, high or low [7]. The financial performance of an entity is said to be healthy when able to 
fulfil the financial obligation under any circumstances by maintaining the daily operations and continuously maintaining the development of the business [8]. For investors, financial performance is a way of seeing the performance generated in the financial sector whether it goes well. Therefore, the company must transparently disclosure of financial statements [9].

\section{RESEARCH METHODS}

Variable managerial ability and financial performance entities are used to test the influence of managerial abilitys on financial performance as measured by earning per share, and return on assets using a descriptive method to solve the problem On this research. Determining the number of samples in this study is done using purposive sampling method based on pre- defined criteria, 1). Financial statements published from 2015 to 2018 on IDX, 2). Experience gains during years of research. The analysis data in this method used a horizontal analysis comparing financial statements, where is the analysis techniques used regression models to test 3 hypotheses. The level of efficiency done by the entity in utilizing resources owned can be done by measuring the output of income and 3 inputs of business load, receivables and business while financial performance with the following ratios. The ratios are Earning per share (EPS) which is net profit margin divided with out standing share [10], and returns on asset divided with total asset [11] .

\section{RESUlTS AND DiscUSSION}

The result of assumption classic results showed that value of normality data with Kolmogorov-Smirnov is 1.246 . it means our data is normal. The value of tolerance and VIF $\mathrm{KM}$ to multicollinearity tests of each valued at 1 . Heteroscedasticity test show that data points spread, unassembled and patterned while the Durbin Watson values to autocorrelation test is $1.502<1.895>1.373$. It means, the variables are no correlation each other while adjusted $R$. Square is $26,6 \%$ which indicates that the variable of managerial ability only has an influence of $26.6 \%$ to measure the level of influence on improving the financial performance. Output t-test and f-test showed us that the significant value of managerial ability to earning per share is 0.000 and the value of t-test is 6.882. It means,

we accepted HO which means managerial ability affects the increase in corporate financial performance. Managerial ability to return on assets showed the t-test 7.319 and the value of significant 0.000 . It means, we accepted $\mathrm{H} 0$ which means managerial ability affects the increase in corporate financial performance.

We said an entity is a good enough when they reaches a level of efficiency that can be gained from a managerial ability to utilize its resources. Managerial abilitys in this study are positively correlated to earning per share and return on asset. This results in demonstrating the managerial ability of the entity in utilizing the resources owned to increase earning per share and return on asset value 2015 for $98 \%$, 2016 for $94 \%, 2017$ for $91 \%$ and 2018 for $99 \%$. The managerial ability to leverage resources owned to increase earning per share shows the level of efficiencies that entities achieve on average value.
We can not compared the earning per share with other entities' earning per share caused by the number of shares that each entities circulated is differently. However, the principle of earning per share is an entities with a high value of earning per share has more opportunity to convince the investors to invest. The value of earning per share in this test annually reaching an average of 122.01 for 2015, 124, 41 for 2016, 103 for 2017 and 116 for 2018. Similarly, an entity with a high return on asset value is capable of demonstrating the managerial ability to benefit from the operation of the entity by utilizing resources or assets owned. The value of return on assets in this study showed the average entity utilizing assets to earn profit annually of 0.08 year $2015,0.07$ year 2017, 0.04 year 2017 and 0.06 year 2018 .

The value of return on asset can be utilized by internal or external parties to take a policy of expanding or policy related to the company's strategy in achieving the expected level of efficiency and the material consideration of investors to make investments. Managerial ability to achieve earning per share and return on asset is not separated from managerial ability in managing entity organization and how managerial takes decisions give impact to the survival of the entity.

This is accordance with the results of studies found that the entity with good managerial ability is better able to suppress the possibility of fraud in reporting financial ability, which means good managerial abilities are able to improve financial performance[12]. The managerial abilities are positively influential when associated with Performance of the company. This evidenced by more empowered entity of investing, providing debts and generating. Profitability during the time the crisis occurs when profitability is inadequate [13].

\section{CONCLUSION}

The results suggest that the managerial ability of an entity can be considered good if it has done maximum efficiency using resources owned. The impact of this resource used is the increase in the quality of financial performance reflected in the value of EPS and ROA. It can be concluded that the managerial ability of an entity has a positive effect on financial.

\section{ACKNOWLEDGMENT}

Thankyou, the authors said to Department of Accounting, University of Musamus Merauke, Indonesia for all the supported to be able to publish the results of this research.

\section{REFERENCES}

[1] Krishnan, G., and C. W. "The relation between managerial ability and audit fees and going concern opinions," Audit. A J. Pract. Theory, 2015.

[2] P. Demerjian, B. Lev, and S. McVay, "Quantifying managerial ability: A new measure and validity tests," Manage. Sci., vol. 58, no. 7, pp. 1229-1248, 2012

[3] P. R. Demerjian, B. Lev, M. F. Lewis, and S. E. McVay, "Managerial ability and earnings quality," Account. Rev., vol. 88, no. 2, pp. 463498, 2013.

[4] Indra Isnugrahadi; Indra Wijaya Kusuma, "Pengaruh Kecakapan Manajerial Terhadap Manajemen Laba Dengan Kualitas Auditor Sebagai Variabel Pemoderasi," J. dan Pros. SNA - Simp. Nas. Akunt., vol. 2, no. 2, pp. 190-200, 2013.

[5] Murhadi; Werner R., Analisis Laporan Keuangan Proyeksi dan Valuasi Saham. 2015. 
[6] Rubianti, “Analisa Rasi Keuangan Untuk Menilai Kinerja Perusahaan Pada PT. Admiral Lines Cabang Tanjungpinang," Univ. Marit. Raja Ali Haji, 2013.

[7] $\mathrm{Hj}$. Nuraini Rasyid, "Analisis Biaya Operasional Terhadap Kinerja Keuangan Pada PT. Bank Negara Indonesia (Persero) Tbk Cabang Makassar," Akmen J. Imiah e-ISSN 2621-4377, vol. 10, no. 2, pp. 233-241, 2013.

[8] M. A. Barus, N. Sudjana, and S. Sulasmiyati, "Penggunaan Rasio Keuangan Untuk Mengukur Kinerja Keuangan Perusahaan," J. Adm. Bisnis, vol. 44, no. 01, pp. 154-163, 2017.

[9] Julastari and A. S. Dewi, "Hubungan Kausal antara Kepemilikan Manajerial, Dewan Direksi dan Kinerja Keuangan pada Perusahaan Manufaktur yang Terdaftar di Bursa Efek Indonesia," INA-Rxiv, 2019.

[10] Gitman L. J, Principles of Managerial Finance 12th Edition. Pearson, 2009.

[11] Munawir, Analisa Laporan Keuangan (Ke-empat). Yogyakarta: Liberty. 2007., 2014.

[12] Z. Wang, M. H. Chen, C. L. Chin, and Q. Zheng, "Managerial ability, political connections, and fraudulent financial reporting in China," $J$. Account. Public Policy, 2017.

[13] D. E. and C. L. Panayiotis C. Andreou, "Managerial Ability and Firm Performance: Evidence from the Global Financial Crisis," J. Bus. Res., vol. 79, no. C, pp. 107-122, 2017. 